\title{
Sphingosinicella microcystinivorans gen. nov., sp. nov., a microcystin-degrading bacterium
}

Correspondence
Tomoko Maruyama
maruyamat@mwj.co.jp

The hepatotoxic microcystins, produced by several members of the cyanobacterial genera Microcystis, Anabaena, Nostoc and Oscillatoria ( = Planktothrix), may causes serious disease in humans and animals (Jochimsen et al., 1998;

Published online ahead of print on 2 December 2005 as DOI 10.1099/ ijs.0.63789-0.

The GenBank/EMBL/DDBJ/accession numbers for the 16S rRNA gene sequences of strains $\mathrm{Y}^{\top}$, MDB2 and MDB3 are AB084247, AB219940 and AB219941. Shizuoka 422-8529, Japan
Tomoko Maruyama, ${ }^{1}$ Ho-Dong Park, ${ }^{2}$ Kazuhiko Ozawa, ${ }^{2}$ Yoshinori Tanaka, ${ }^{3}$ Tatsuo Sumino, ${ }^{4}$ Koei Hamana, ${ }^{5}$ Akira Hiraishi ${ }^{6}$ and Kenji Kato ${ }^{7}$

\author{
${ }^{1}$ Marine Works Japan Ltd, Kamariyahigashi, 2-16-32 4F, Kanazawa-ku, Yokohama 236-0042, \\ Japan \\ ${ }^{2}$ Department of Environmental Sciences, Faculty of Science, Shinshu University, Asahi, 3-1-1, \\ Matsumoto 390-8621, Japan \\ ${ }^{3}$ Department of Microbiology and Immunology, Graduate School of Medicine, Tohoku University, \\ Seiryo-machi, 2-1, Aoba-ku, Sendai 980-8575, Japan \\ ${ }^{4}$ Hitachi Plant Engineering \& Construction Co., Ltd, Matsudo 271-0064, Japan \\ ${ }^{5}$ Department of Laboratory Sciences, School of Health Sciences, Faculty of Medicine, Gunma \\ University, Showa-machi 3chome, 39-15, Maebashi 371-8514, Japan \\ ${ }^{6}$ Department of Ecological Engineering, Toyohashi University of Technology, Toyohashi \\ 441-8580, Japan
}

${ }^{7}$ Department of Biology and Geosciences, Faculty of Science, Shizuoka University, Oya, 836,

Three strains of bacteria that degrade the cyanobacterial hepatotoxin microcystin, $\mathrm{Y}^{\top}, \mathrm{MDB} 2$ and MDB3, were isolated from a eutrophic lake, Lake Suwa, and the Tenryu River, Japan, and characterized. These strains were aerobic and chemo-organotrophic and their cells were Gram-negative, non-spore-forming rods, motile by means of single polar flagella. Yellow-pigmented colonies were formed on nutrient agar media. The strains assimilated only citrate among the organic compounds tested as carbon sources. The $\mathrm{G}+\mathrm{C}$ content of genomic DNA ranged from 63.6 to $63.7 \mathrm{~mol} \%$. Phylogenetic analysis based on 16S rRNA gene sequences indicated that the new isolates formed a tight cluster within the family Sphingomonadaceae but were clearly separate from established genera of this family, e.g. Sphingomonas, Sphingobium, Novosphingobium and Sphingopyxis; sequence similarities between the new isolates and type strains from established genera ranged from 90.9 to $94.9 \%$. Chemotaxonomic and phenotypic data supported the conclusion that these strains were members of the family Sphingomonadaceae. The major components of the cellular fatty acids were $18: 1 \omega 7 c(36-41 \%)$ and $16: 1 \omega 7 c(33-36 \%)$. Hydroxy fatty acids were mainly 2-OH $14: 0$ (11-13\%), and $3-\mathrm{OH}$ fatty acids were absent. Glycosphingolipids were detected. Ubiquinone-10 and homospermidine were present as the major quinine and polyamine, respectively. Thus, it is proposed that the three strains represent a new genus and species of the family Sphingomonadaceae with the name Sphingosinicella microcystinivorans gen. nov., sp. nov. The type strain is $\mathrm{Y} 2^{\top}\left(=\mathrm{KCTC} 12019^{\top}=\mathrm{JCM} 13185^{\top}\right)$.
Kuiper-Goldman et al., 1999). A microcystin-degrading bacterium designated strain $\mathrm{Y}^{\mathrm{T}}$ was isolated using diluted nutrient agar (Nissui Pharmaceutical) from a eutrophic lake, Lake Suwa, Japan, during the blooming period of toxic Microcystis (Park et al., 2001). This strain was able to degrade microcystin-RR, -YR and -LR and its isomer 6(Z)-Adda microcystin-LR and to grow in inorganic media containing microcystin as the sole carbon source as well as in diluted nutrient broth (Park et al., 2001). A phylogenetic analysis of strain $\mathrm{Y} 2^{\mathrm{T}}$ based on $16 \mathrm{~S}$ rRNA gene sequences revealed that 
it represents a deeply branching lineage within the cluster of the sphingomonads, including the genera Blastomonas, Novosphingobium, Sphingobium, Sphingopyxis and Sphingomonas (Park et al., 2001). Later, we isolated two other strains (MDB2 and MDB3) of microcystin-degrading bacteria from the Tenryu River in Japan. These strains were phylogenetically similar to strain $\mathrm{Y}^{\mathrm{T}}$. In the present study, we describe the taxonomic properties of these three strains of microcystin degraders and propose to classify them in a novel genus and species.

General cell morphology, Gram reaction, spore formation and motility by means of flagella were studied under an Olympus light microscope (U-LH 1000) by NCIMB Japan (Shizuoka, Japan). Colony shape was observed after the cells were incubated at $30^{\circ} \mathrm{C}$ for $48 \mathrm{~h}$ on nutrient agar (Oxoid). Biochemical tests were performed by NCIMB Japan using an API 20NE kit according to the manufacturer's instructions (API bioMérieux) and by conventional tests for activity of catalase and oxidase, gas/acid production from glucose and oxidation/fermentation from glucose, as described previously (Barrow \& Feltham, 1993). Analysis of cellular fatty acids was performed by NCIMB Japan using the Sherlock Microbial Identification system (version 5.0; MIDI Inc.) according to the manufacturer's instructions. Cellular fatty acids were extracted from cells grown on trypticase soy (SCD) agar (Becton Dickinson) at $30^{\circ} \mathrm{C}$ for $24 \mathrm{~h}$ and analysed as methyl esters. Glycosphingolipids were analysed by TLC as described previously (Takeuchi et al., 2001). Respiratory quinone profiles were studied as described previously (Hiraishi et al., 1996; Iwasaki \& Hiraishi, 1998). Polyamines were analysed as previously reported (Hamana \& Takeuchi, 1998; Hamana et al., 2003). Genomic DNA was extracted and purified by the phenol extraction method as described previously (Saito \& Miura, 1963) and DNA base composition was determined by the HPLC method of Katayama-Fujimura et al. (1984). After genomic DNA was prepared by the PrepMan method (Applied Biosystems), $16 \mathrm{~S}$ rRNA genes were amplified by PCR and sequenced with a MicroSeq Full 16S rDNA Bacterial Sequencing kit (Applied Biosystems) by NCIMB Japan. Sequence similarities were studied using the BLAST program (Altschul et al., 1997). Related sequences including type strains of established genera of the family Sphingomonadaceae were obtained from GenBank/EMBL/DDBJ. Multiple alignments of sequence data, calculation of evolutionary distances and construction of a neighbour-joining phylogenetic tree (Saitou \& Nei, 1987) were performed with the CLUSTAL $\mathrm{W}$ program (Thompson et al., 1994) using bootstrap values based on 1000 replications.

Strains $\mathrm{Y}^{\mathrm{T}}$, MDB2 and MDB3 were Gram-negative, nonspore-forming rods measuring $0 \cdot 6-0 \cdot 7 \mu \mathrm{m}$ in width and $0 \cdot 8-1 \cdot 0 \mu \mathrm{m}$ in length. Cells were motile by means of single polar flagella. All three strains formed yellow colonies on nutrient agar (Oxoid) after $48 \mathrm{~h}$ incubation at $30^{\circ} \mathrm{C}$. The temperature range for growth was $10-37^{\circ} \mathrm{C}$ and the optimum temperature was $30^{\circ} \mathrm{C}$. No growth occurred at $45^{\circ} \mathrm{C}$. The $\mathrm{pH}$ range for growth was $7-9$. The strains were strictly aerobic and chemo-organotrophic. They exhibited positive reactions for oxidase and catalase but negative reactions in the oxidation/fermentation test and gas/acid production test with glucose. Other physiological and biochemical characteristics of strains $\mathrm{Y}^{\mathrm{T}}, \mathrm{MDB} 2$ and MDB3 were compared with those of type strains of the phylogenetically related genera Sphingomonas, Sphingobium, Novosphingobium and Sphingopyxis (Table 1). In assimilation tests using 12 carbon sources, strains $\mathrm{Y}^{\mathrm{T}}, \mathrm{MDB} 2$ and $\mathrm{MDB} 3$ were shown to assimilate citrate only. The strains did not assimilate glucose, L-arabinose, D-mannose, $N$-acetyl-Dglucosamine, maltose, gluconate, $\mathrm{n}$-caproate, adipate, DLmalic acid or phenylacetate. Strains $\mathrm{Y}^{\mathrm{T}}$, MDB2 and MDB3 exhibited negative reactions for all other phenotypic tests: nitrate reduction, $\beta$-galactosidase, aesculin hydrolysis, urease, gelatin hydrolysis, indole production, glucose fermentation and arginine dihydrolase. A negative reaction for nitrate reduction, which was proposed as a phenotypic marker to distinguish the four genera of the family Sphingomonadaceae (Takeuchi et al., 2001), was characteristic of Sphingobium, Novosphingobium and some species of Sphingomonas.

As shown in Table 2, the major fatty acids of the three strains were $18: 1 \omega 7 c(36-41 \%)$ and $16: 1 \omega 7 c(33-36 \%)$. Minor fatty acids were $16: 0(7-8 \%), 16: 1 \omega 5 c(3 \%)$ and $14: 0$ (1-2\%). The main component of the hydroxy fatty acids

Table 1. Biochemical characteristics of strains $Y 2^{\top}, M D B 2$, MDB3 and related type strains

Strains: 1, strain $\mathrm{Y}^{\mathrm{T}}$ (strains MDB2 and MDB3 showed identical results); 2, Sphingomonas adhaesiva IFO $15099^{\mathrm{T}}$; 3, Sphingomonas paucimobilis IFO $13935^{\mathrm{T}}$; 4, Sphingobium yanoikuyae IFO $15102^{\mathrm{T}}$; 5, Novosphingobium capsulatum IFO $12533^{\mathrm{T}} ; 6$, Sphingopyxis terrae IFO $15098^{\mathrm{T}} ; 7$, Sphingopyxis macrogoltabida IFO $15033^{\mathrm{T}}$. Data in columns 2 and 5-7 are from Takeuchi et al. (2001) and data in columns 3 and 4 are from Ushiba et al. (2003). All strains were positive for assimilation of citrate. All strains were negative for assimilation of phenylacetate, urease activity, gelatin hydrolysis, indole production, glucose fermentation and arginine dihydrolase.

\begin{tabular}{|lcccccccc|}
\hline Characteristic & $\mathbf{1}$ & $\mathbf{2}$ & $\mathbf{3}$ & $\mathbf{4}$ & $\mathbf{5}$ & $\mathbf{6}$ & $\mathbf{7}$ \\
\hline Assimilation of: & & & & & & & & \\
$\quad$ Glucose & - & - & + & + & - & - & - \\
L-Arabinose & - & + & + & + & + & + & + \\
D-Mannose & - & + & + & - & + & + & + \\
D-Mannitol & - & + & - & - & + & + & + \\
N-Acetyl-D-glucosamine & - & + & + & + & + & + & + \\
Maltose & - & + & + & + & + & + & + \\
Gluconate & - & + & - & + & + & + & + \\
n-Caproate & - & + & - & - & + & + & + \\
Adipate & - & + & - & - & + & + & + \\
DL-Malic acid & - & + & + & + & + & + & + \\
Nitrate reduction & - & - & + & - & + & - & - \\
$\beta$-Galactosidase & - & + & + & + & + & - & + \\
Aesculin hydrolysis & - & + & + & + & + & - & + \\
& & & & & & & & \\
\hline
\end{tabular}


Table 2. Major fatty acids of strains $Y 2^{\top}, M D B 2$ and MDB3

Values are percentages of total fatty acid content. tr, Trace $(<1 \%) ;-$, not detected.

\begin{tabular}{|lccc|}
\hline Fatty acid & Y2 $^{\mathbf{T}}$ & MDB2 & MDB3 \\
\hline $12: 0$ & - & - & $\operatorname{tr}$ \\
$14: 0$ & 1 & 2 & 2 \\
$16: 0$ & 8 & 7 & 7 \\
$16: 1 \omega 5 c$ & 3 & 3 & 3 \\
$16: 1 \omega 7 c$ & 34 & 33 & 36 \\
$17: 1 \omega 6 c$ & $\operatorname{tr}$ & $\operatorname{tr}$ & 1 \\
$18: 0$ & $\operatorname{tr}$ & $\operatorname{tr}$ & $\operatorname{tr}$ \\
$18: 1 \omega 5 c$ & 1 & 1 & 1 \\
$18: 1 \omega 7 c$ & 38 & 41 & 36 \\
$11-$ Methyl $18: 1 \omega 7 c$ & $\operatorname{tr}$ & - & $\operatorname{tr}$ \\
$2-\mathrm{OH} 12: 0$ & $\operatorname{tr}$ & - & $\operatorname{tr}$ \\
$2-\mathrm{OH} 14: 0$ & 12 & 11 & 13 \\
$2-\mathrm{OH} 15: 0$ & $\operatorname{tr}$ & - & $\operatorname{tr}$ \\
$2-\mathrm{OH} 16: 0$ & 1 & 1 & 1 \\
$2-\mathrm{OH} 16: 1$ & $\operatorname{tr}$ & - & $\operatorname{tr}$ \\
iso 3-OH $16: 0$ & $\operatorname{tr}$ & $\operatorname{tr}$ & $\operatorname{tr}$ \\
\hline
\end{tabular}

was 2-OH 14:0 (11-13\%), and 3-OH fatty acids were absent. Analysis of lipid extracts by TLC revealed the presence of glycosphingolipids in all three strains. The major respiratory quinone was Q-10. The polyamine detected was homospermidine $\left[1.5 \mu \mathrm{mol}\right.$ (g wet cells) $\left.{ }^{-1}\right]$, as reported for the genus Sphingomonas. The DNA G+C content of the three strains ranged from $63 \cdot 6$ to $63 \cdot 7 \mathrm{~mol} \%$.

The 16S rRNA gene sequences of strains $\mathrm{Y}^{\mathrm{T}}, \mathrm{MDB} 2$ and MDB3 determined were continuous stretches of 1449, 1482 and $1482 \mathrm{bp}$, respectively. The three strains showed $99.9 \%$ sequence similarity to each other, suggesting that they form a genetically coherent group at the species level. Similarity searches with the sequences using the BLAST program indicated that the closest relatives of our strains were unidentified strains 7CY (99.5\%; GenBank accession no. AB076083; Ishii et al., 2004), B9 (99.3\%; AB159609; Harada et al., 2004) and IC075 (99.3\%; AB196249; Inoue et al., 2005). Strains 7CY and B9 were also microcystin-degrading bacteria, isolated independently from Lake Suwa. The microcystin-degrading processes of strains 7CY and B9 were quite similar to that of strain $\mathrm{Y} 2^{\mathrm{T}}$, as several common degradation products were detected (Park et al., 2001; Harada et al., 2004; Ishii et al., 2004). Saito et al. (2003)

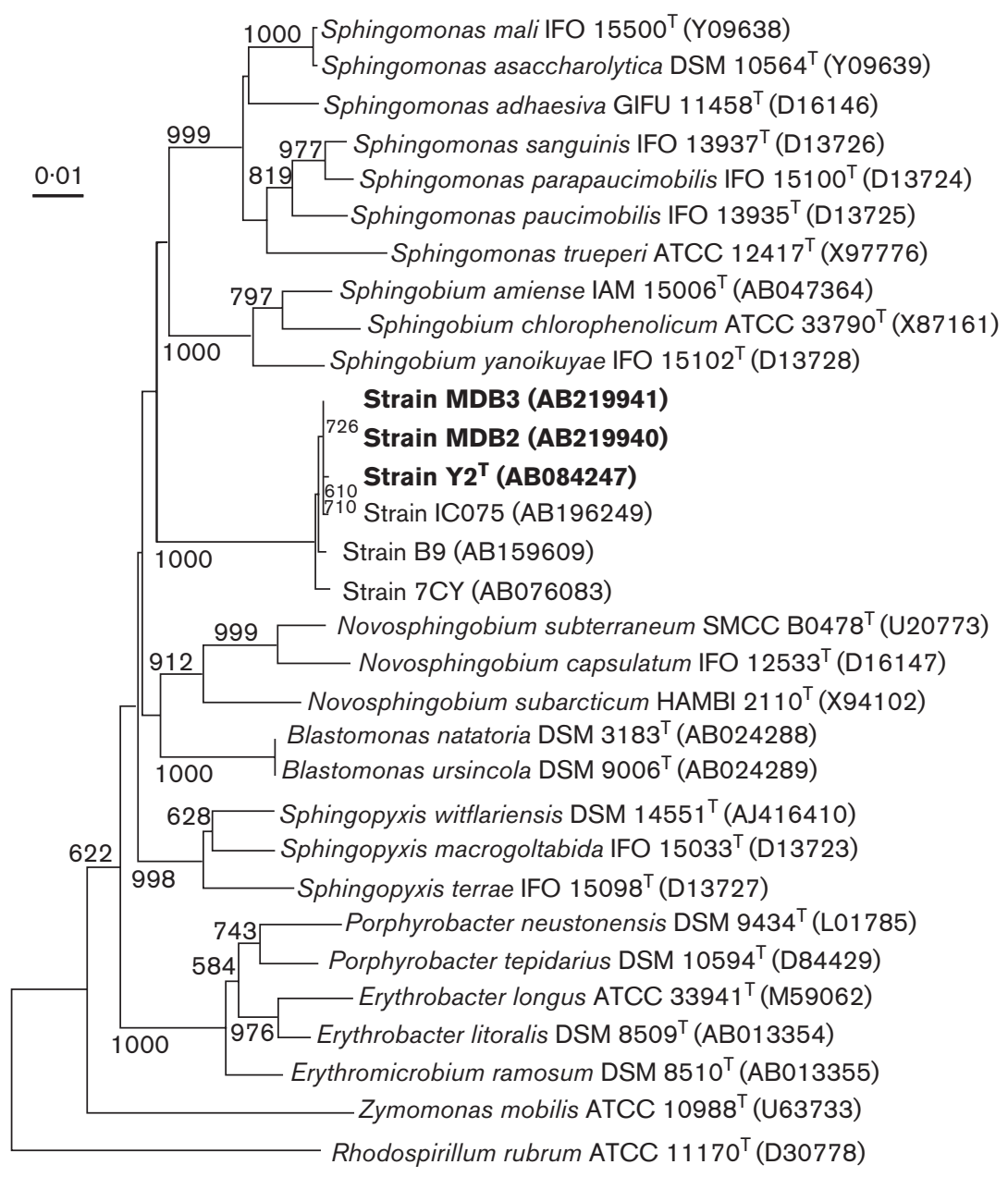

Fig. 1. Distance-matrix tree based on $16 \mathrm{~S}$ rRNA gene sequences showing phylogenetic relationships between strains $\mathrm{Y} 2^{\top}$, MDB2 and MDB3 and the type species of representative genera of the family Sphingomonadaceae. The sequence of Rhodospirillum rubrum ATCC $11170^{\top}$ was used as an outgroup to root the tree. The phylogenetic tree was constructed by the neighbour-joining method (Saitou \& Nei, 1987). Bootstrap values from 1000 trials are shown at branch points of interest. Bar, $1 \%$ nucleotide substitution. 
reported that strain $\mathrm{Y} 2^{\mathrm{T}}$ possessed a gene, $m l r A$, that encodes a hydrolytic enzyme to open the cyclic peptide of microcystins (Bourne et al., 2001). These findings suggest that strains $\mathrm{Y}^{\mathrm{T}}$, 7CY and B9 are highly similar. Strain IC075 was able to degrade carbazole, which is an aromatic compound similar in structure to dioxins. Although there has been no report of the ability of strain IC075 to degrade microcystin, the high $16 \mathrm{~S}$ rRNA gene sequence similarity between strains $\mathrm{Y}^{\mathrm{T}}$ and IC075 implies that the latter strain may be able to degrade microcystin. A phylogenetic tree based on $16 \mathrm{~S}$ rRNA gene sequences revealed that strains $\mathrm{Y}^{\mathrm{T}}$, MDB2 and MDB3 formed a distinct clade together with strains 7CY, B9 and IC075 within the family Sphingomonadaceae (Kosako et al., 2000). However, this clade was separate from any of the established genera of this family, in particular Sphingomonas, Sphingobium, Novosphingobium and Sphingopyxis (Fig. 1); strains $\mathrm{Y}^{\mathrm{T}}$, MDB2 and MDB3 showed $16 \mathrm{~S}$ rRNA gene sequence similarity of $90 \cdot 9-94 \cdot 4 \%$ to the type strains of the respective type species.

To find nucleotide signatures specific to the 16S rRNA of the genera of the family Sphingomonadaceae (Takeuchi et al., 2001), we aligned the sequences of strains $\mathrm{Y}^{\mathrm{T}}$, MDB2, MDB3, 7CY, B9 and IC075. Nucleotide signatures specific to the $16 \mathrm{~S}$ rRNAs of strains $\mathrm{Y}^{\mathrm{T}}$, MDB2 and MDB3 were the same as those of the genus Sphingomonas sensu stricto reported by Takeuchi et al. (2001), i.e. C: G at position $52: 359, \mathrm{G}$ at position $134, \mathrm{G}$ at position $593, \mathrm{G}: \mathrm{C}$ at position $987: 1218$ and $U: G$ at position $990: 1215$ (Escherichia coli numbering; Brosius et al., 1978). The same nucleotide signatures were found in the other microcystin degraders strains 7CY (Ishii et al., 2004) and B9 (Harada et al., 2004) and the carbazole-utilizing strain IC075 (Inoue et al., 2005).

As described above, the phylogenetic data demonstrate clearly that strains $\mathrm{Y}^{\mathrm{T}}, \mathrm{MDB} 2$ and MDB3 are members of the family Sphingomonadaceae. However, since strains $\mathrm{Y}^{\mathrm{T}}{ }^{\mathrm{T}}$, MDB2 and MDB3 form a distinct phylogenetic cluster within this family, it is difficult to allocate them to any of the previously described genera (Fig. 1). 16S rRNA gene sequence similarities between strains $\mathrm{Y}^{\mathrm{T}}$, MDB2, MDB3 and the type strains of species of established genera were low, ranging from $90 \cdot 9$ to $94 \cdot 9 \%$. Takeuchi et al. (2001) reported that the genera of the family Sphingomonadaceae were separated at approximately $<95 \% 16 \mathrm{~S}$ rRNA gene sequence similarity. Chemotaxonomic and phenotypic data support the conclusion that these strains are members of the family Sphingomonadaceae (Tables 1 and 2). Glycosphingolipids and ubiquinone-10 were present. Strains $\mathrm{Y}^{\mathrm{T}}, \mathrm{MDB} 2$ and MDB3 contained $18: 1 \omega 7 c$ and $16: 1 \omega 7 c$ as the dominant fatty acids and 2-OH 14:0 as the major hydroxy fatty acid (Takeuchi et al., 1993, 2001; Kämpfer et al., 1997; Tiirola et al., 2005) and 3-OH fatty acids were absent (Takeuchi et al., 1993) (Table 2). The polyamine of the microcystindegrading strains was homospermidine, as was the case for the genus Sphingomonas sensu stricto, whereas all other genera noted above contained spermidine (Takeuchi et al.,
2001; Hamana et al., 2003). The ability to reduce nitrate was absent from our strains as well as from Sphingobium and Sphingopyxis strains.

By a combination of a number of chemotaxonomic and phenotypic characteristics listed above (see Tables 1 and 2), together with phylogenetic information of the formation of a distinct clade within the family Sphingomonadaceae and low $16 \mathrm{~S}$ rRNA gene sequence similarity $(<95 \%)$ to related genera, it is most appropriate to conclude that these novel microcystin-degrading strains should be classified in a novel genus and species of the family Sphingomonadaceae. The name Sphingosinicella microcystinivorans gen. nov., sp. nov. is proposed for the three strains.

\section{Description of Sphingosinicella gen. nov.}

Sphingosinicella (Sphin.go.si'ni.cel'la. N.L. n. sphingosinum sphingosine; L. fem. n. cella a store-room and in biology a cell; N.L. fem. n. Sphingosinicella sphingosine-containing cell).

Cells are Gram-negative, non-spore-forming rods, motile by means of polar flagella. Colonies are yellow. Strictly aerobic and chemo-organotrophic. Catalase- and oxidase-positive. Nitrate is not reduced to nitrite. The major fatty acids are $18: 1 \omega 7 c$ and $16: 1 \omega 7 c$. 2-Hydroxy fatty acids are present, with 2-OH 14:0 predominating. 3-Hydroxy fatty acids are absent. Glycosphingolipids are produced. Respiratory quinone is predominantly Q-10. Homospermidine is the major polyamine component, as for the genus Sphingomonas. Placed phylogenetically in the family Sphingomonadaceae. The characteristic 16S rRNA signatures are the same as for the genus Sphingomonas: $52: 359$ (C:G), $134(\mathrm{G}), 593(\mathrm{G})$, $987: 1218(\mathrm{G}: \mathrm{C})$ and $990: 1215(\mathrm{U}: \mathrm{G})$. The type species is Sphingosinicella microcystinivorans.

\section{Description of Sphingosinicella microcystinivorans sp. nov.}

Sphingosinicella microcystinivorans (mi.cro.cys'ti.ni.vo' rans. N.L. n. microcystinum microcystin; L. part. adj. vorans devouring; N.L. part. adj. microcystinivorans microcystindegrading).

Shows the following properties in addition to those given in the genus description. Cells are $0 \cdot 3-0 \cdot 7 \times 0 \cdot 6-1 \cdot 0 \mu \mathrm{m}$. Citrate only is assimilated. Negative reactions are observed for hydrolysis of aesculin, gelatin and urease, activity of $\beta$-galactosidase, indole production, glucose fermentation, arginine dihydrolase and assimilation of glucose, Larabinose, D-mannose, $\mathrm{N}$-acetyl-D-glucosamine, maltose, gluconate, n-caproate, adipate, DL-malic acid and phenylacetate. Major fatty acids are $18: 1 \omega 7 c(33-36 \%)$ and $16: 1 \omega 7 c(36-41 \%) ; 16: 0(7-8 \%), 16: 1 \omega 5 c(3 \%)$ and $14: 0(1-2 \%)$ are produced as minor components. Major 2-hydroxy fatty acid is $2-\mathrm{OH} 14: 0(11-13 \%) ; 2-\mathrm{OH} 16: 0$ $(1 \%)$ is produced as a minor component. Polyamine is homospermidine $\left.[1.5 \mu \mathrm{mol} \text { (g wet cells })^{-1}\right]$. The DNA $\mathrm{G}+\mathrm{C}$ content is $63 \cdot 6-63 \cdot 7 \mathrm{~mol} \%$. 
The type strain, strain $\mathrm{Y}^{\mathrm{T}}\left(=\mathrm{KCTC} 12019^{\mathrm{T}}=\mathrm{JCM}\right.$ $\left.13185^{\mathrm{T}}\right)$, was isolated from a toxic Microcystis blooming lake, Lake Suwa, Japan. Strains MDB2 and MDB3, isolated from the Tenryu River, Japan, are reference strains.

\section{References}

Altschul, S. F., Madden, T. F., Schaffer, A. A., Zhang, J., Zhang, Z., Miller, W. \& Lipman, D. J. (1997). Gapped BLAST and PSI-BLAST: a new generation of protein database search programs. Nucleic Acids Res 25, 3389-3402.

Barrow, G. I. \& Feltham, R. K. A. (1993). Cowan and Steel's Manual for the Identification of Medical Bacteria, 3rd edn. Cambridge: Cambridge University Press.

Bourne, D. G., Riddles, P., Jones, G. J., Smith, W. \& Blakeley, R. L. (2001). Characterisation of a gene cluster involved in bacterial degradation of the cyanobacterial toxin microcystin LR. Environ Toxicol 16, 523-534.

Brosius, J., Palmer, M. L., Kennedy, P. J. \& Noller, H. F. (1978). Complete nucleotide sequence of a $16 \mathrm{~S}$ ribosomal RNA gene from Escherichia coli. Proc Natl Acad Sci U S A 75, 4801-4805.

Hamana, K. \& Takeuchi, M. (1998). Polyamine profiles as chemotaxonomic markers within alpha, beta, gamma, delta, and epsilon subclass of class Proteobacteria: distribution of 2-hydroxyputrescine and homospermidine. Microbiol Cult Coll 14, 1-14 (in Japanese).

Hamana, K., Sakamoto, A., Tachiyanagi, S., Terauchi, E. \& Takeuchi, M. (2003). Polyamine profiles of some members of the alpha subclass of the class Proteobacteria: polyamine analysis of 20 recently described genera. Microbiol Cult Coll 19, 13-21 (in Japanese).

Harada, K., Imanishi, S., Kato, H., Mizuno, M., Ito, E. \& Tsuji, K. (2004). Isolation of Adda from microcystin-LR by microbial degradation. Toxicon 44, 107-109.

Hiraishi, A., Ueda, Y., Ishihara, J. \& Mori, T. (1996). Comparative lipoquinone analysis of influent sewage and activated sludge by highperformance liquid chromatography and photodiode array detection. $J$ Gen Appl Microbiol 42, 457-470.

Inoue, K., Habe, H., Yamane, H., Omori, T. \& Nojiri, H. (2005). Diversity of carbazole-degrading bacteria having the car gene cluster: isolation of a novel gram-positive carbazole-degrading bacterium. FEMS Microbiol Lett 245, 145-153.

Ishii, H., Nishijima, M. \& Abe, T. (2004). Characterization of degradation process of cyanobacterial hepatotoxins by a gram-negative aerobic bacterium. Water Res 38, 2667-2676.

Iwasaki, M. \& Hiraishi, A. (1998). A new approach to numerical analysis of microbial quinone profiles in the environment. Microbes Environ 13, 67-76.

Jochimsen, E. M., Carmichael, W. W., An, J. S. \& 9 other authors (1998). Liver failure and death after exposure to microcystins at a hemodialysis center in Brazil. N Engl J Med 338, 873-878.
Kämpfer, P., Denner, E. B. M., Meyer, S., Moore, E. R. B. \& Busse, H.-J. (1997). Classification of "Pseudomonas azotocolligans" Anderson 1955, 132, in the genus Sphingomonas as Sphingomonas trueperi sp. nov. Int J Syst Bacteriol 47, 577-583.

Katayama-Fujimura, Y., Komatsu, Y., Kuraishi, H. \& Kaneko, T. (1984). Estimation of DNA base composition by high performance liquid chromatography of its nuclease P1 hydrolysate. Agric Biol Chem 48, 3169-3172.

Kosako, Y., Yabuuchi, E., Naka, T., Fujiwara, N. \& Kobayashi, K. (2000). Proposal of Sphingomonadaceae fam. nov., consisting of Sphingomonas Yabuuchi et al. 1990, Erythrobacter Shiba and Shimidu 1982, Erythromicrobium Yurkov et al. 1994, Porphyrobacter Fuerst et al. 1993, Zymomonas Kluyver and van Niel 1936, and Sandaracinobacter Yurkov et al. 1997, with the type genus Sphingomonas Yabuuchi et al. 1990. Microbiol Immunol 44, 563-575.

Kuiper-Goldman, T., Falconer, I. \& Fitzgerald, J. (1999). Human health aspects. In Toxic Cyanobacteria, pp. 113-152. Edited by I. Chorus \& J. Bartram. London: E. \& F. N. Spon.

Park, H.-D., Sasaki, Y., Maruyama, T., Yanagisawa, E., Hiraishi, A. \& Kato, K. (2001). Degradation of the cyanobacterial hepatotoxin microcystin by a new bacterium isolated from a hypertrophic lake. Environ Toxicol 16, 337-343.

Saito, H. \& Miura, K. (1963). Preparation of transforming deoxyribonucleic acid by phenol treatment. Biochim Biophys Acta 72, 619-629.

Saito, T., Okano, K., Park, H.-D., Itanaka, T., Inamori, Y., Neilan, B. A., Burns, B. P. \& Sugiura, N. (2003). Detection and sequencing of the microcystin LR-degrading gene, $m l r A$, from new bacteria isolated from Japanese lakes. FEMS Microbiol Lett 229, 271-276.

Saitou, N. \& Nei, M. (1987). The neighbor-joining method: a new method for reconstructing phylogenetic trees. Mol Biol Evol 4, 406-425.

Takeuchi, M., Kawai, F., Shimada, Y. \& Yokota, A. (1993). Taxonomic study of polyethylene glycol-utilizing bacteria: emended description of the genus Sphingomonas and new descriptions of Sphingomonas macrogoltabidus sp. nov., Sphingomonas sanguis sp. nov., and Sphingomonas terrae sp. nov. Syst Appl Microbiol 16, 227-238.

Takeuchi, M., Hamana, K. \& Hiraishi, A. (2001). Proposal of the genus Sphingomonas sensu stricto and three new genera, Sphingobium, Novosphingobium and Sphingopyxis, on the basis of phylogenetic and chemotaxonomic analyses. Int J Syst Evol Microbiol 51, 1405-1417.

Thompson, J. D., Higgins, D. G. \& Gibson, T. J. (1994). CLUSTAL W: improving the sensitivity of progressive multiple sequence alignment through sequence weighting, position-specific gap penalties and weight matrix choice. Nucleic Acids Res 22, 4673-4680.

Tiirola, M. A., Busse, H.-J., Kämpfer, P. \& Männistö, M. K. (2005). Novosphingobium lentum sp. nov., a psychrotolerant bacterium from a polychlorophenol bioremediation process. Int J Syst Evol Microbiol 55, 583-588.

Ushiba, U., Takahara, Y. \& Ohta, H. (2003). Sphingobium amiense sp. nov., a novel nonylphenol-degrading bacterium isolated from a river sediment. Int J Syst Evol Microbiol 53, 2045-2048. 